\title{
Systematics of Xanthorrhoeaceae sensu lato: evidence for polyphyly
}

\author{
Paula Rudall and Mark W. Chase
}

\begin{abstract}
Rudall, Paula and Chase, Mark W. (Jodrell Laboratory, Royal Botanic Gardens, Kew, Richmond, Surrey TW9 3DS, United Kingdom) 1996. Systematics of Xanthorrhoeaceae sensu lato: evidence for polyphyly. Telopea 6(4): 629-647. This paper reviews the systematics of the ten genera of Xanthorrhoeaceae sensu lato in the light of significant new anatomical and molecular data which indicate that it is a polyphyletic assemblage. Dasypogon, Calectasia, Kingia and Baxteria belong together in Dasypogonaceae in the commelinoid clade, rather than with the other genera in the order Asparagales (Lilianae). Xanthorrhoea is taxonomically isolated and correctly placed in a monotypic family Xanthorrhoeaceae. The family Lomandraceae should include Acanthocarpus, Chamaexeros, Lomandra, Xerolirion and Romnalda (not Baxteria), together with other genera (the arthropodioids).
\end{abstract}

\section{Introduction}

Ten genera (Table 1) were listed in Xanthorrhoeaceae sensu lato in the Flora of Australia (1986). For convenience, this grouping followed Cronquist (1981) and Hutchinson (1934), although as several authors (e.g. Waterhouse 1967, Staff \& Waterhouse 1981) have indicated, the genera concerned form two or three natural groupings which are probably not related at the family level. Dahlgren et al. (1985) referred six of them to a separate family, Dasypogonaceae, and Calectasia to a monotypic family Calectasiaceae, leaving only Xanthorrhoea in Xanthorrhoeaceae, although they retained the whole group in the same order, Asparagales (Table 2). Romnalda and Xerolirion were described recently and have not been included in most treatments. Brummitt (1992), following recommendations from Bedford, listed six of the genera as belonging to Lomandraceae Lotsy. Many species of Xanthorrhoea, Kingia and Dasypogon are trees or shrubs with remarkably similar vegetative morphology, although Xanthorrhoea has a complex 'spike' inflorescence and Kingia and Dasypogon have capitulate inflorescences. The other genera are mainly fibrous herbs, with varying inflorescence morphology (Table 3).

A review of the systematics of this group is timely in the light of significant new data, both anatomical (Rudall \& Caddick 1994, and this paper) and molecular ( $r b c \mathrm{~L}$ : Chase et, al. 1995a) which indicate that Dasypogon, Calectasia, Kingia and Baxteria belong to the commelinoid clade, rather than with Xanthorrhoea and Lomandra in Asparagales. The commelinoid clade (Chase et al. 1993), which includes the grasses, sedges, rushes, palms and gingers, is fairly well supported (Chase et al. 1995a, 1995b), although some analyses exclude the gingers. (Stevenson \& Loconte 1995). There are several characters that distinguish it more or less effectively from other monocots (including Asparagales), such as cell wall fluorescence (Rudall \& Caddick 1994), stomatal type, surface waxes and silica (largely a commelinoid character). Furthermore, a secondary thickening meristem distinguishes several groups within the asparagoids and is restricted to the asparagoid clade among monocots, although not present in all (Rudall 1995). These characters are reviewed here, together with other characters of systematic significance in the group, such as pollen (Chanda \& Ghosh 1976) and ovules (Rudall 1994) (Table 4). 
Table 1. Genera of Xanthorrhoeaceae sensu lato

$\begin{array}{llll}\text { Genus } & \text { Publication year } & \text { No. spp. } & \text { Distribution } \\ \text { Acanthocarpus Lehm. } & 1846 & 7 & \text { SW Australia } \\ \text { Baxteria R.Br. ex Hook. } & 1843 & 1 & \text { SW Australia } \\ \text { Calectasia R.Br. } & 1820 & 3 & \text { SW \& S/E Australia } \\ \text { Chamaexeros Benth. } & 1878 & 3 \text { or } 4 & \text { SW Australia } \\ \text { Dasypogon R.Br. } & 1810 & 3 & \text { SW Australia } \\ \text { Kingia R.Br. } & 1825 & 1 & \text { SW Australia } \\ \text { Lomandra Labill. } & 1804 & 50 & \text { Australia, New Guinea (2), } \\ & 1978 & 3 & \text { New Caledonia (1) } \\ \text { Romnalda P. Stevens } & & & \text { New Guinea (1), } \\ \text { Xanthorrhoea Smith } & 1798 & 28 & \text { Queensland (2) } \\ \text { Xerolirion A.S. George } & 1986 & 1 & \text { SW Australia }\end{array}$

\section{Material and methods}

The slides made for Fahn's $(1954,1961)$ investigations are present in the slide collection at the Royal Botanic Gardens, Kew (labelled below as F). In addition, some slides were prepared for this investigation from dried material in the Kew Herbarium (K) and from fixed material collected by one of us (PJR) in Australia, for which voucher specimens are deposited in the Western Australian Herbarium (PERTH) and the National Herbarium of New South Wales (NSW).

Acanthocarpus Lehm.: A. preissii Lehm. (F: 2 specimens; \& K: Melville 71, Cranfield 160). Baxteria R.Br. ex Hook.: B. australis R.Br. (F; \& K: Mann 122, Melville 4463).

Calectasia R.Br.: C. cyanea R.Br. (F; \& PERTH: Rudall 37 \& 41; \& K: Morrison s.n.).

Chamaexeros Benth.: C. fimbriata (F.Muell.) Benth. (K: Wilson 8715), C. serra (Endl.) Benth. (F; \& K: Armstrong 85/134).

Dasypogon R.Br.: D. bromeliifolius R.Br. (F; \& PERTH: Rudall 32), D. hookeri J.L.

Drumm. (F; \& PERTH: Rudall 29), D. obliquifolius Lehm. (K: Mann \& George 76).

Kingia R.Br.: K. australis R.Br. (F; \& PERTH: Rudall 30; \& K: Morrison 8287).

Lomandra Labill.: (F: 29 species, including L. collina (R.Br.) Ewart, L. obliqua), L. hastilis (R.Br.) Ewart (PERTH: Rudall 44), L. preissii (Endl.) Ewart (PERTH: Rudall 19).

Romnalda P.Stevens: R. grallata R.Henderson (K: Henderson \& Clarkson H2640, Clarkson 3648), R. papuana (Lauterb.) P. Stevens (K: J.Van Dijk 24).

Xanthorrhoea Smith: several species, including X. australis (F; \& K: NGW 3013).

Xerolirion A.S.George: X. divaricata (K: A.S. George 14321).

Field-collected material was fixed in formalin acetic alcohol (FAA) and stored in $70 \%$ alcohol. Herbarium material was boiled in water to rehydrate it. For light microscope (LM) observations, sections of leaves and stems were cut using a Reichert sliding microtome, stained with safranin and Alcian blue, dehydrated through an alcohol series to $100 \%$ alcohol, then Histoclear, then mounted on microscope slides in Euparal. Photomicrographs were taken using a Leitz Diaplan photomicroscope. 
Table 2. Summary of taxonomic placements

\begin{tabular}{|c|c|c|c|c|c|}
\hline Genus & Bentham \& Hooker 1880 & Krause 1930 & Hutchinson 1934 & Dahlgren et al. 1985 & Brummitt 1992 \\
\hline Acanthocarpus & Juncaceae - Xeroteae & $\begin{array}{l}\text { Liliaceae - Asphodeloideae } \\
\text { - Lomandreae }\end{array}$ & $\begin{array}{l}\text { Agavales - } \\
\text { Xanthorrhoeaceae }\end{array}$ & $\begin{array}{l}\text { Asparagales - } \\
\text { Dasypogonaceae }\end{array}$ & Lomandraceae \\
\hline Calectasia & Juncaceae - Calectasieae & $\begin{array}{l}\text { Liliaceae - Asphodeloideae } \\
\text { - Calectasieae }\end{array}$ & $\begin{array}{l}\text { Agavales - } \\
\text { Xanthorrhoeaceae }\end{array}$ & $\begin{array}{l}\text { Asparagales - } \\
\text { Calectasiaceae }\end{array}$ & Calectasiaceae \\
\hline Chamaexeros & Juncaceae - Xeroteae & $\begin{array}{l}\text { Liliaceae - Asphodeloideae } \\
\text { - Lomandreae }\end{array}$ & $\begin{array}{l}\text { Agavales - } \\
\text { Xanthorrhoeaceae }\end{array}$ & $\begin{array}{l}\text { Asparagales - } \\
\text { Dasypogonaceae }\end{array}$ & Lomandraceae \\
\hline Dasypogon & Juncaceae - Xeroteae & $\begin{array}{l}\text { Liliaceae - Asphodeloideae } \\
\text { - Dasypogoneae }\end{array}$ & $\begin{array}{l}\text { Agavales - } \\
\text { Xanthorrhoeaceae }\end{array}$ & $\begin{array}{l}\text { Asparagales - } \\
\text { Dasypogonaceae }\end{array}$ & Dasypogonaceae \\
\hline Kingia & Juncaceae - Calectasieae & $\begin{array}{l}\text { Liliaceae - Asphodeloideae } \\
\text { - Calectasieae }\end{array}$ & $\begin{array}{l}\text { Agavales - } \\
\text { Xanthorrhoeaceae }\end{array}$ & $\begin{array}{l}\text { Asparagales - } \\
\text { Dasypogonaceae }\end{array}$ & Dasypogonaceae \\
\hline Romnalda & & & & & Lomandraceae \\
\hline Xanthorrhoea & Juncaceae - Xeroteae & $\begin{array}{l}\text { Liliaceae - Asphodeloideae } \\
\text { - Lomandreae }\end{array}$ & $\begin{array}{l}\text { Agavales - } \\
\text { Xanthorrhoeaceae }\end{array}$ & $\begin{array}{l}\text { Asparagales - } \\
\text { Xanthorrhoeaceae }\end{array}$ & Xanthorrhoeaceae \\
\hline
\end{tabular}


Table 3. Inflorescences and flowers (Bedford et al. 1986, Stevens 1978, Waterhouse 1967)

\begin{tabular}{|c|c|c|c|c|}
\hline Genus & inflorescence & flowers & tepals & o. ovules per locule \\
\hline Acanthocarpus & $\begin{array}{l}\text { cymose clusters } \\
\text { or racemes }\end{array}$ & bisexual & petaloid & 1 \\
\hline Baxteria & single flowers & bisexual & petaloid & 1 \\
\hline Calectasia & single flowers & bisexual & $\begin{array}{l}\text { scarious, } \\
\text { but colourful }\end{array}$ & 1 \\
\hline Chamaexeros & cymose panicles & bisexual & petaloid & 2 \\
\hline Dasypogon & $\begin{array}{l}\text { capitulum } \\
\text { (with 4-flowered } \\
\text { clusters) }\end{array}$ & bisexual & dry \& glumaceous & 1 \\
\hline Kingia & $\begin{array}{l}\text { capitulum } \\
\text { (derived from } \\
\text { simple raceme } \\
\text { or spike) }\end{array}$ & bisexual & dry, scarious & 1 \\
\hline Lomandra & $\begin{array}{l}\text { cymose clusters } \\
\text { or spikes/ single } \\
\text { flowers }\end{array}$ & $\begin{array}{l}\text { mostly } \\
\text { unisexual }\end{array}$ & petaloid & 1 \\
\hline Romnalda & cymose clusters & bisexual & petaloid & 2 \\
\hline Xanthorrhoea & $\begin{array}{l}\text { spike (based on } \\
\text { contracted cymes) }\end{array}$ & bisexual & $\begin{array}{l}\text { outer } 3 \text { dry, } \\
\text { scarious, inner } \\
3 \text { petaloid }\end{array}$ & several \\
\hline Xerolirion & solitary $(f)$, cymes $(m)$ & unisexual & petaloid & 1 \\
\hline
\end{tabular}

Table 4. Information on pollen (Chanda \& Ghosh 1976) and ovule structure (Rudall 1994 and unpublished)

\begin{tabular}{|c|c|c|c|c|}
\hline Genus & pollen & pollen surface & micropyle & $\begin{array}{l}\text { embryo sac } \\
\text { \& nucellus }\end{array}$ \\
\hline Acanthocarpus & sulculate & punctitegillate & unknown & unknown \\
\hline Baxteria & $\begin{array}{l}\text { large, } \\
\text { complex } \\
\text { 'unipantocolpate' }\end{array}$ & reticulate & unknown & unknown \\
\hline Calectasia & $\begin{array}{l}\text { sulcate ( } 3 \\
\text { parallel opercula) }\end{array}$ & reticulate & oi \& ii & $\begin{array}{l}\text { es small, with massive } \\
\text { storage nucellus }\end{array}$ \\
\hline Chamaexeros & sulculate & negatively reticulate & ii only & $\begin{array}{l}\text { chalazal dermal cells of } \\
\text { nucellus enlarged; } \\
\text { giant antipodals }\end{array}$ \\
\hline Dasypogon & sulcate & punctate to scrobilate & oi \& ii & $\begin{array}{l}\text { es small, with massive } \\
\text { storage nucellus }\end{array}$ \\
\hline Kingia & extended-sulcate & punctate/psilate. & oi \& ii & unknown \\
\hline Lomandra & $\begin{array}{l}\text { sulcate, } \\
\text { spiraperturate, } \\
\text { irregular }\end{array}$ & $\begin{array}{l}\text { spinulose, } \\
\text { echinate, } \\
\text { reticulate etc }\end{array}$ & ii only & $\begin{array}{l}\text { chalazal dermal cells of } \\
\text { nucellus enlarged; } \\
\text { giant antipodals }\end{array}$ \\
\hline Romnalda & unknown & unknown & ii only & $\begin{array}{l}\text { chalazal dermal cells of } \\
\text { nucellus enlarged; } \\
\text { giant antipodals }\end{array}$ \\
\hline Xanthorrhoea & extended-sulcate & reticulate & ii only & $\begin{array}{l}\text { hypostase present; } \\
\text { thick micropylar } \\
\text { nucellar 'beak' }\end{array}$ \\
\hline Xerolirion & unknown & unknown & unknown & unknown \\
\hline
\end{tabular}

ii $=$ inner integument, oi $=$ outer integument, es $=$ embryo sac 
For silica analysis, thick leaf sections were dried using a Balzers CPD 020 critical point drier, then mounted onto stubs and carbon-coated using a Fisons TB 500 Temcarb carbon coater. They were then examined using a Link Analytical QX 2000 X-ray analyser and a Cambridge Instruments Stereoscan 240 SEM.

\section{Results}

\section{Secondary thickening meristem (STM)}

Radially-aligned vascular bundles, derived from an STM, are present in the woody underground rhizome of several species of Lomandra (Fig 2a), including L. confertifolia, L. filiformis, L. juncea, L. obliqua and L. preissii. Fahn (1954) also reported an STM in Lomandra, but the observation has been discounted by some authors because the genus is herbaceous. Xanthorrhoea also has an STM, but an STM is lacking in Kingia and Dasypogon (Waterhouse 1967).

\section{Leaf anatomy}

In previous anatomical works on this group, Fahn $(1954,1961)$ described the leaf anatomy of Acanthocarpus preissii, Baxteria australis, Calectasia (two species), Chamaexeros, (two species), Dasypogon (two species), Kingia australis, Lomandra (33 species) and Xanthorrhoea (12 species). Staff (in Stevens 1978) described the leaf anatomy of Romnalda papuana. Detailed descriptions are therefore not given here, but taxonomically significant characters are presented (Table 5).

Leaf surface Surface waxes are generally present but not oriented in parallel lines or long wax ribbons in any of the genera.

Branched hairs occur on the leaf of Calectasia (Fig. 3c), especially at the margins, and in Dasypogon large multicellular epidermal structures are present at the leaf margins, sometimes extending into branched hairs. Baxteria and Kingia apparently lack hairs on most of the leaf, although long multicellular hairs are present at the leaf bases in Kingia. Unbranched unicellular hairs (papillae) are present surrounding stomata in Xerolirion and also in species of Acanthocarpus, Chamaexeros, Lomandra and Xanthorrhoea.

Acanthocarpus, Chamaexeros, Lomandra and Xerolirion (Fig. 4c) have anomocytic stomata and elongated epidermal cells (typical of Asparagales), although in Lomandra (Tomlinson 1974) paracytic or tetracytic types are sometimes present, formed by oblique cell divisions. In Lomandra preisii a typical agenous ontogeny was observed (Fig. 1a), which leads after cell elongation to the anomocytic type, although sometimes with oblique end walls. Baxteria, Kingia (Fig. 3a) and Xanthorrhoea have paracytic/ tetracytic stomata; Tomlinson (1974) recorded oblique cell divisions in Xanthorrhoea, but Baxteria and Kingia are still unknown in this respect. Calectasia and Dasypogon closely resemble each other in that all mature epidermal cells are short and polyhedral or irregular in shape, with several cells surrounding the stomata. In Dasypogon bromeliifolius both mesogene and perigene cells were observed, and both oblique and non-oblique divisions in cells adjacent to the meristemoid (Fig. 1b,c).

Leaf TS Superficially, leaf structure in cross sections of Kingia australis and Xanthorrhoea australis is remarkably similar (Fig. 2d, f), mirroring the strong similarity of these two genera in vegetative morphology. Both have quadrangular leaves, modified substomatal cells and phloem in two distinct strands in each vascular bundle, and also more taxonomically widespread characters such as raphides absent and stomata tetracytic. Both have an outermost chlorenchymatous region, of 2-3 
Table 5. Summary of vegetative anatomical characters (mainly leaf)

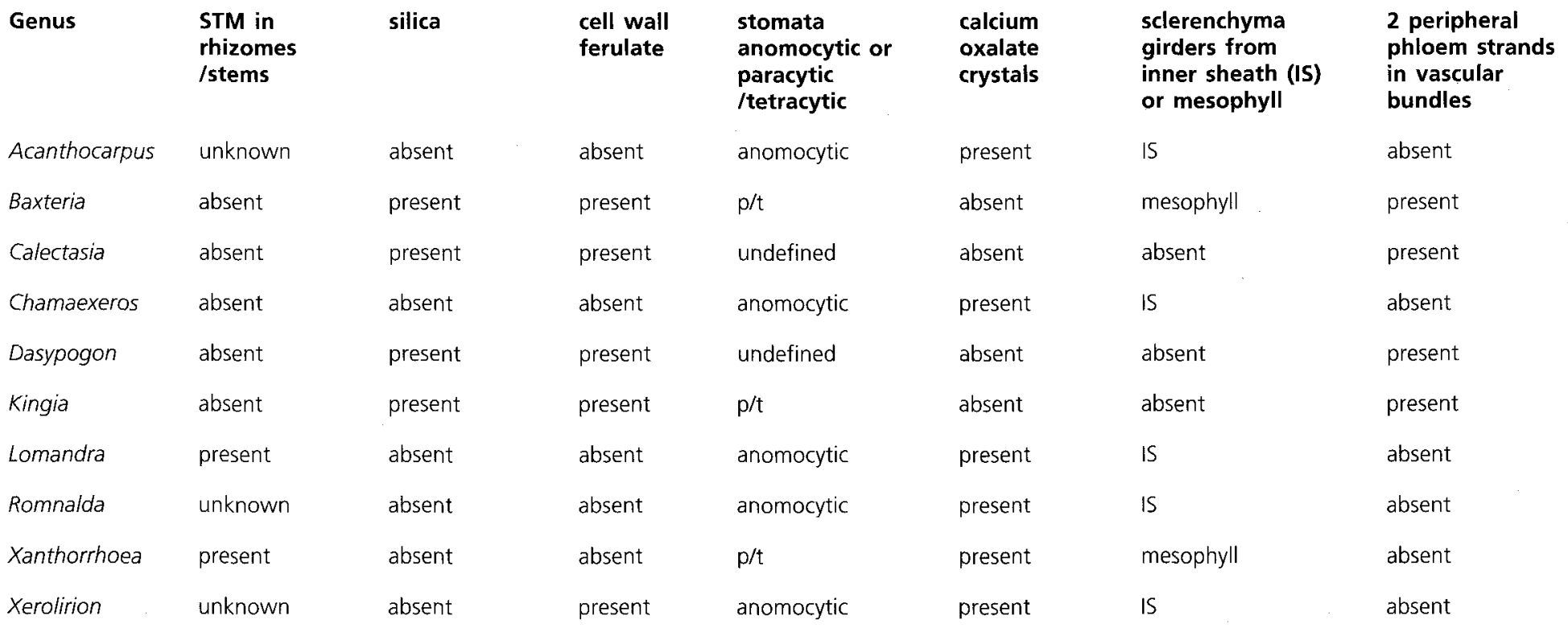



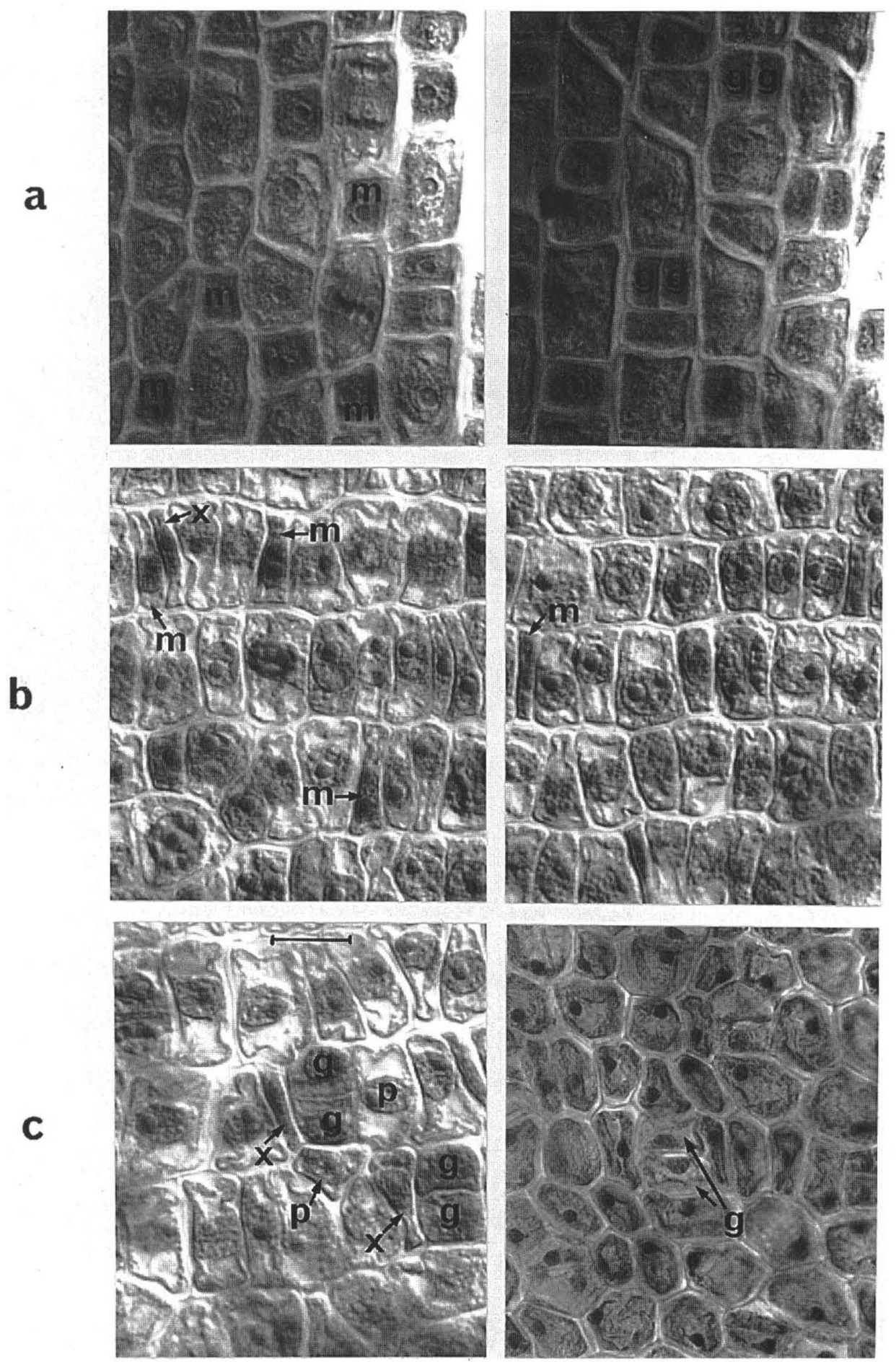

Fig. 1. Stomatal development. a, Lomandra preisii, agenous development, with equal divisions in cells adjacent to the meristemoid, sometimes forming oblique end walls; $\mathbf{b}, \mathbf{c}$, Dasypogon bromeliifolius, both mesogene and perigene cells present. ( $\mathrm{g}$ = guard cell, $\mathrm{m}=$ meristemoid, $\mathrm{p}=$ perigene cell, $\mathrm{x}=$ mesogene cell). Scale bar $=10 \mu \mathrm{m}$. 
layers of palisade cells, and an inner parenchymatous region with vascular bundles. Both have a somewhat lignified hypodermal layer, clearly a xeromorphic feature (Fahn 1954). However, they differ from each other in several significant respects. In Kingia australis the vascular bundles are in a single row (all similarly oriented) with thick-walled fibres present in an arc at the phloem poles and interspersed in the phloem, also with a larger region of thinner-walled fibrous cells present within the outer bundle sheaths (but never extending to the epidermis). In Xanthorrhoea australis (Fig. 2f) the vascular bundles are in 2-4 rows, oriented in opposite directions (i.e. leaf isobilateral, in contrast to all the other genera in question), and in the outer chlorenchymatous region there are sclerenchymatous girders formed from mesophyll tissue (rather than bundle sheath) linking the epidermis with the central parenchymatous region (Fig. 3f). Not all species of Xanthorrhoea have quadrangular leaves: some are U- or V-shaped in cross section (David Bedford, pers. comm.).

In all the other genera, leaves are usually more or less U- or V-shaped in cross section (sometimes somewhat flattened in strap-like leaves), with vascular bundles in a single row (all similarly oriented). Baxteria (Fig. 3b) resembles Kingia in having both phloem fibres and a larger region of thinner-walled fibrous cells present within the outer bundle sheaths, but differs in having sclerenchymatous girders extending from the outer bundle sheath cells to the epidermis, i.e. formed from mesophyll tissue, as they are distinct from outer bundles sheath cells. This differs from the condition in Xanthorrhoea, where the girders do not extend from the bundles. Baxteria and Kingia also often have two peripheral phloem strands at vascular bundles, as in Dasypogon and Calectasia.

Dasypogon (Fig. 2e, 3e) differs from all the other genera in having chlorenchyma present only on the abaxial side of the leaf and with a broad adaxial parenchymatous region containing the vascular bundles, which often have two peripheral strands of phloem. Calectasia (Fig. 2b) has a reduced leaf with only three vascular bundles, each with at least two peripheral strands of phloem. It resembles Dasypogon in lacking girders and having a thick, sclerenchymatous inner bundle sheath completely encircling the xylem and phloem regions of the vascular bundles.

Xerolirion (Fig. 4a-c) also has a reduced leaf, with about three vascular bundles, but differs from Calectasia in that it has sclerenchyma girders (formed from the inner bundle sheath, as in the Lomandra-group), which extend along the abaxial epidermis, sometimes becoming isolated in small groups, as in Romnalda.

Acanthocarpus (Fig. 2g) and Chamaexeros (Fig. 3d) resemble each other in having sclerenchyma girders of inner bundle sheath cells and enlarged parenchymatous outer bundle sheath cells, both characters also shared with Lomandra (Fig. 2c) and Romnalda. Romnalda grallata (Fig. $4 \mathrm{~d}, \mathrm{e}$ ) and $R$. papuana both also have small isolated subepidermal abaxial and adaxial groups of fibres in the mesophyll, although these were not recorded by Staff (in Stevens 1978) for $R$. papuana, and may be variable.

\section{Silica and calcium oxalate}

Calcium oxalate raphides (bundles of fine needle-like crystals) are present in leaf mesophyll of Acanthocarpus, Chamaexeros, Romnalda, Xerolirion (and rarely Lomandra), often in enlarged idioblasts. In Calectasia and Dasypogon raphides were not observed in the leaves but are common in the flower. In Baxteria and Kingia raphides were not observed in any tissues or organs; indeed, they appear to lack calcium oxalate entirely. In Xanthorrhoea raphides were not observed in material examined here, but rhomboidal calcium oxalate crystals or styloids are present in occasional mesophyll cells, bundle sheath cells and epidermal cells of some species of both Lomandra and Xanthorrhoea (Fig. 5d). 

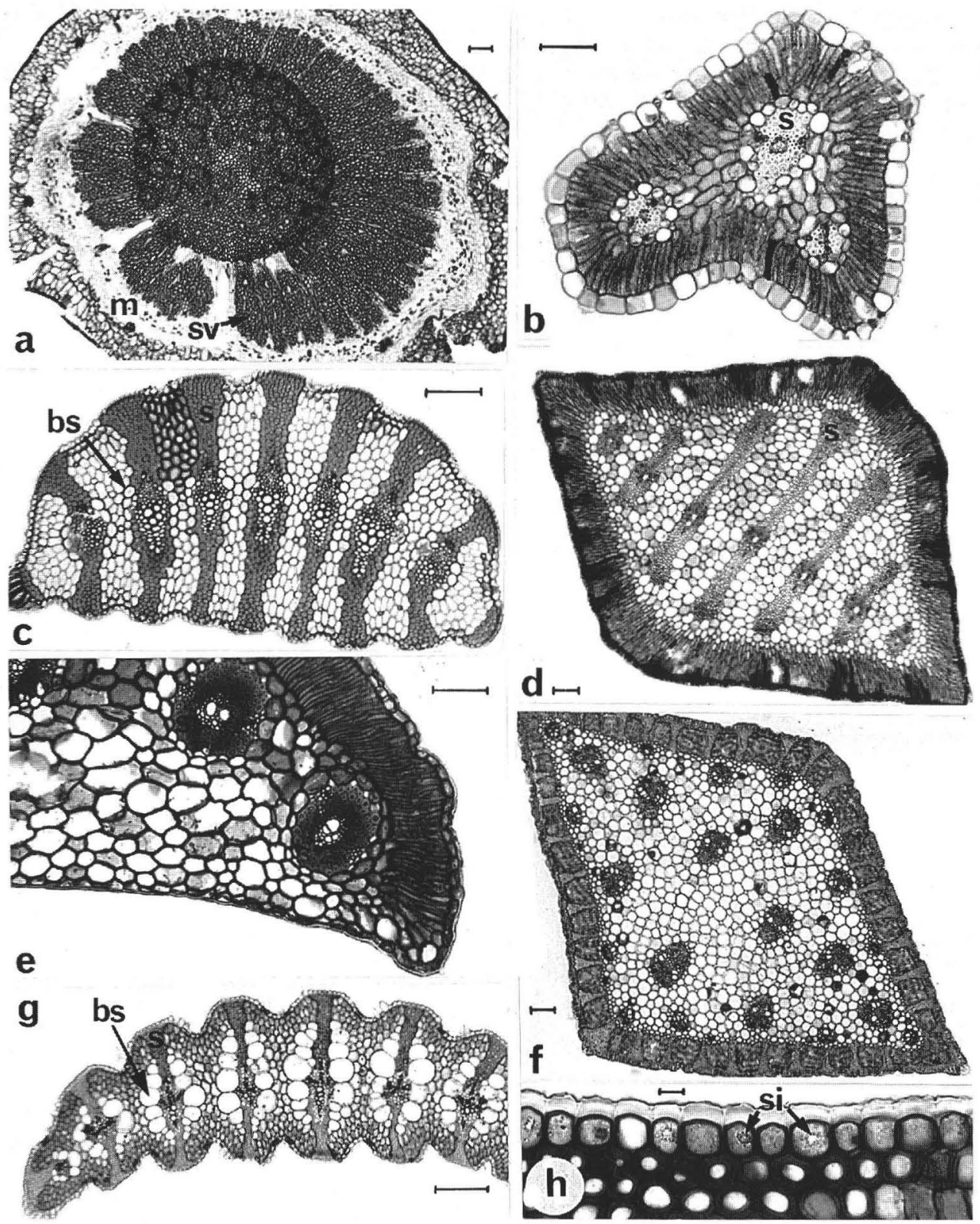

Fig. 2. Transverse sections. a, Lomandra obliqua: rhizome TS, showing radially aligned secondary vascular bundles (sv), produced by secondary thickening meristem (m); b. Calectasia cyanea: leaf TS; c, Lomandra collina: leaf TS; d, Kingia australia: leaf TS; e, Dasypogon bromeliifolius: leaf margin TS; f, Xanthorrhoea australis: leaf TS; g, Acanthocarpus preissii: leaf TS; $\mathbf{h}$, Baxteria australis: leaf epidermis TS, with silica bodies (si). bs = bundle sheath, $\mathrm{s}=$ sclerenchyma. Scale bars $=100 \mu \mathrm{m}$, except in $\mathrm{h}=10 \mu \mathrm{m}$. 
In Kingia (Figs 3a, 4b) and Baxteria (Figs 2h, 5a), spherical (druse-like) silica bodies with a rugose surface are present in the leaf epidermal cells, generally one per cell. These were reported by Fahn (1954) as druses (clustered crystals of calcium oxalate).
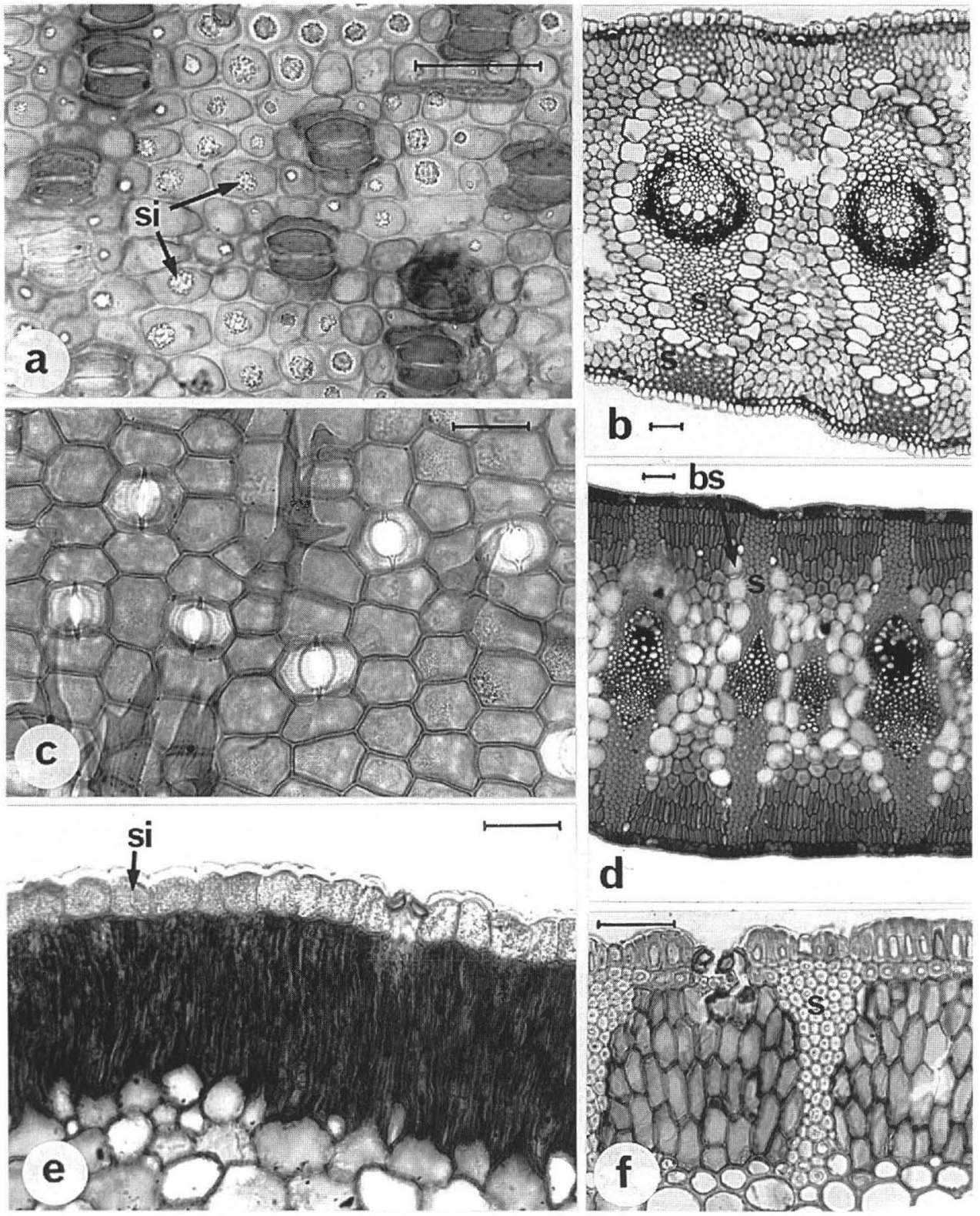

Fig. 3. Leaf anatomy. a, Kingia australis: leaf surface, with silica bodies (si) in epidermal cells, and paracytic/tetracytic stomata; b, Baxteria australis: leaf TS; c, Calectasia cyanea: leaf surface, with branched hairs; d, Chamaexeros serra: leaf TS; e, Dasypogon bromeliifolius: leaf epidermis TS, with silica sand (si); f, Xanthorrhoea australis: leaf epidermis and outer mesophyll TS, with substomatal cells (arrowed). bs $=$ bundle sheath, $\mathrm{s}=$ sclerenchyma. Scale bars $=50 \mu \mathrm{m}$. 
However, they have the typical structure of silica bodies and lack the polarising properties of calcium oxalate crystals. X-ray and SEM examination effectively demonstrates the silicaceous nature of these bodies. Silica is also present in the epidermis of Dasypogon (Figs 3e, 5c) and Calectasia in the form of fine silica sand or amorphous crystals, in most epidermal cells in Dasypogon, although less frequent in Calectasia. Silica is always absent from the other genera examined, including Lomandra and Xanthorrhoea, both of which have polyhedral styloid-like calcium oxalate crystals. In Xanthorrhoea these polyhedral crystals are frequently epidermal, unusually for Asparagales, but X-ray analysis demonstrates that they are not silica (Fig. 5d). In Xerolirion leaves, although epidermal cells appeared to contain bodies, these were extremely small, and we were unable to confirm the presence of silica.
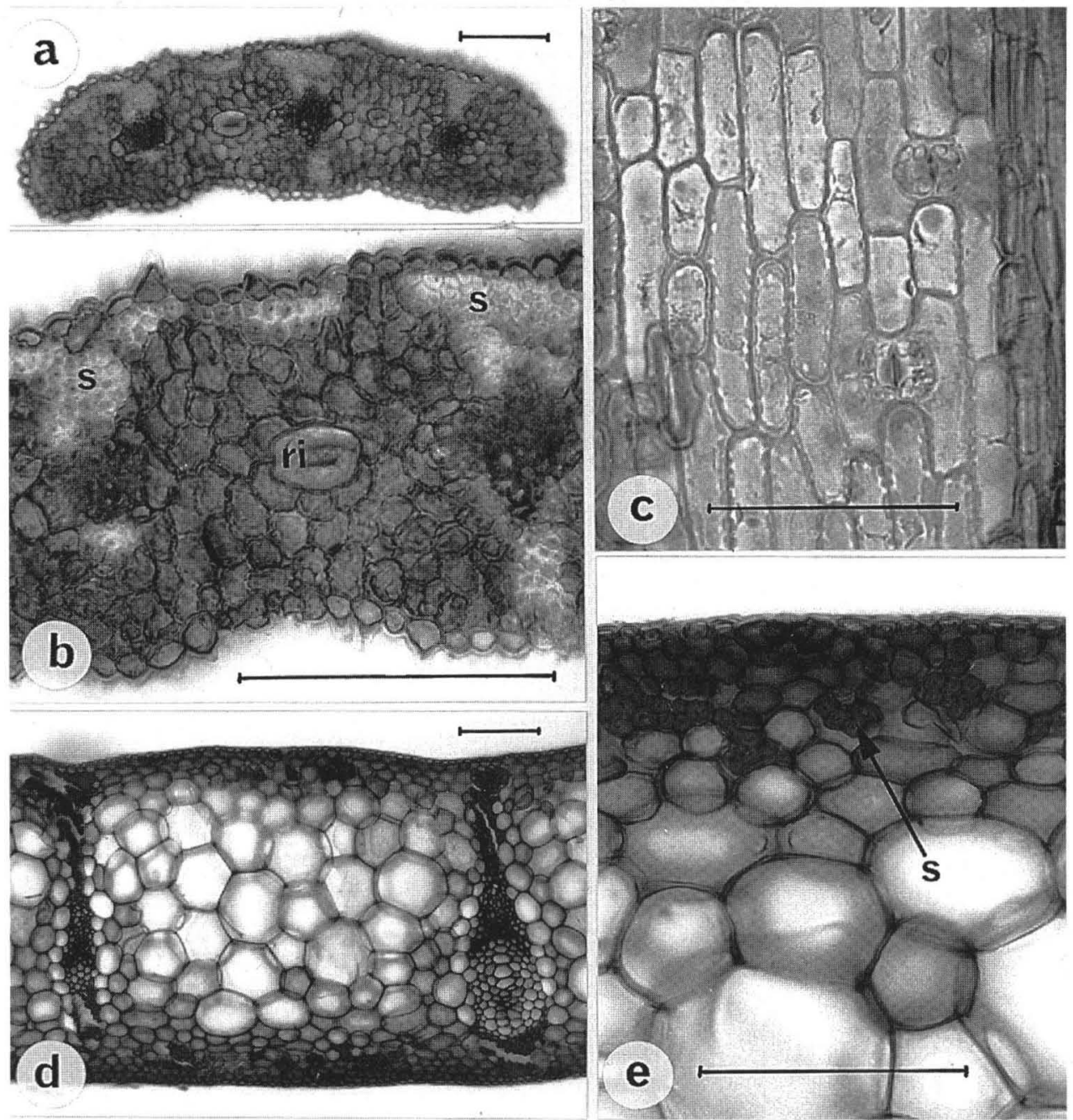

Fig. 4. Leaf anatomy. a-c, Xerolirion divaricata: a,b, leaf TS, with sclerenchyma girders and subepidermal sclerenchyma (s) and raphide idioblast (ri); c, leaf surface, with anomocytic stomata; d,e, Romnalda grallata: leaf TS, with small sclerenchyma bundles (s). Scale bars $=100 \mu \mathrm{m}$, except in $\mathrm{c}=50 \mu \mathrm{m}$. 


\section{Discussion}

\section{Systematic characters}

Secondary thickening meristem (STM) Similarity in habit of some of these genera, especially Xanthorrhoea and Kingia, is a result of different growth mechanisms, representing two non-homologous systems, either with or without a secondary thickening meristem (STM). Waterhouse (1987) cited this as evidence that Xanthorrhoeaceae sensu lato is a 'monstrously unnatural' family. Fahn (1954), Waterhouse (1967) and Staff \& Waterhouse (1967) showed that Xanthorrhoea has an STM, but that this is entirely lacking in Dasypogon and Kingia, in which stem thickening is palm-like, with a broad apical region and sunken apical meristem (i.e. an extensive primary thickening meristem: PTM). Virtually all monocots have a PTM, but among tree-forming monocots this has developed along different lines, probably more than once, either as an extensive apical PTM, as in palms, or as the STM, at some distance from the apex. Among the herbaceous taxa of the group in question, Fahn (1954) could not find an STM in rhizomes of Chamaexeros, Calectasia and Dasypogon, but reported an STM in Lomandra. Later authors (e.g. Stevens 1978, Bedford et al. 1986) have tended to discount this observation, but our investigations confirm that Lomandra does indeed have an STM (Fig. 1a), in common only with some other woody Asparagales (Rudall, 1991, 1995). We also confirm that an STM occurs in Xanthorrhoea, but not in Calectasia, Dasypogon or Kingia. An STM also occurs in Thysanotus (Rudall 1995), which resembles Lomandra (but not Xanthorrhoea) in ovule and embryo sac structure (Rudall 1994).

Leaf anatomy Taxonomically significant leaf anatomical characters in the genera investigated include vascular bundle orientation, and position of sclerenchyma in relation to bundle sheath cells and epidermis. Several of the taxa have girders (sclerenchyma linking the vascular region with the epidermis), but these are clearly non-homologous between the various groups: in Xanthorrhoea they are of mesophyll origin (not associated with vascular bundles), in Baxteria mesophyll or outer bundle sheath, and in the Lomandra-group from the inner bundle sheath. Fahn (1954) described modified substomatal cells in Baxteria, Kingia and sometimes in Dasypogon and Xanthorrhoea. Xerolirion resembles the Lomandra-group in having sclerenchyma girders from the inner bundle sheath.

Although species-level differences are not emphasised here, leaf anatomy may well provide useful characters at this level in some genera, such as Xanthorrhoea and Lomandra. Indeed, Fahn (1954) produced a key to identification of Lomandra species, based entirely on leaf anatomical characters. Leaf anatomy may well help to elucidate relationships within the Lomandra-group (Acanthocarpus, Chamaexeros, Lomandra and Romnalda) and with putatively allied arthropodioid genera such as Arthropodium, Cordyline, Chamaescilla, Eustrephus, Sowerbaea, Thysanotus and Trichopetalum (see below).

Silica The presence of silica in Kingia, Baxteria, Dasypogon and Calectasia supports their inclusion in the commelinoid clade, in which it is commonly present (Chase et al. 1995b). Silica bodies do not otherwise occur in Lilianae sensu Dahlgren et al. (1985), except in orchids (and Hanguana, which is probably commelinoid). Silica bodies are also absent from basal monocot groups, such as Arales, Alismatales and Najadales. In orchids, silica bodies are present in the vascular bundle sheaths, not in the epidermis (Dahl Møller \& Rasmussen 1984), and are of two types: either spherical (in some epiphytic orchids) or conical (in both terrestrial and epiphytic life-forms). Since they do not occur in all orchids, and are absent from other Lilianae, silica bodies probably originated de novo in Orchidales and were subsequently lost in at least one group, as Dahl Møller \& Rasmussen (1984) also concluded. 
In the commelinoid clade, silica bodies may be either epidermal or present in the bundle sheath. Epidermal, spherical (druse-like) silica bodies, similar to those of Kingia and Baxteria, are found in Bromeliaceae, Zingiberaceae, Cyperaceae and Thurniaceae, and also Rapateaceae, where silica bodies may be solitary or numerous, or in the form of fine sand (Tomlinson 1969). Spherical silica bodies occur in various other commelinoid monocots, such as Arecaceae, Cannaceae, Costaceae, Marantaceae, Musaceae and Strelitziaceae, but usually in the bundle sheath cells adjacent to sclerenchyma, never in the epidermal cells.

a
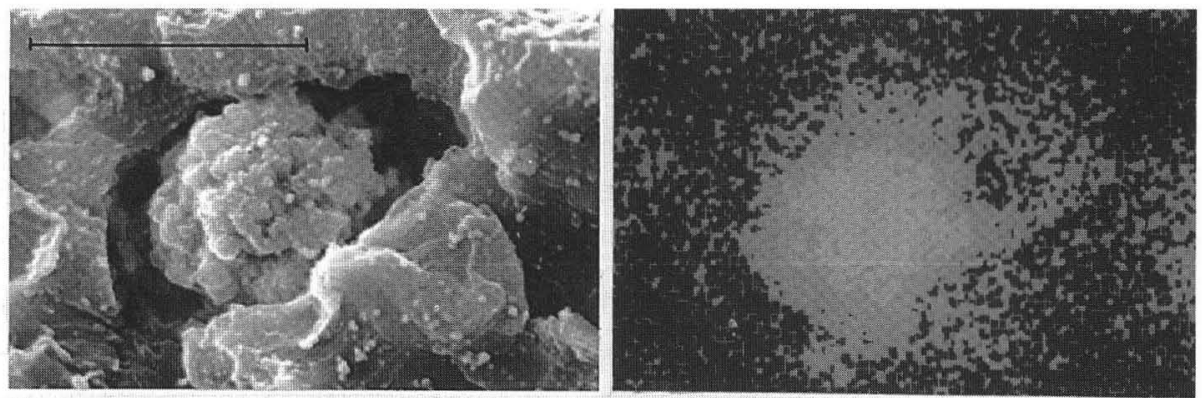

b
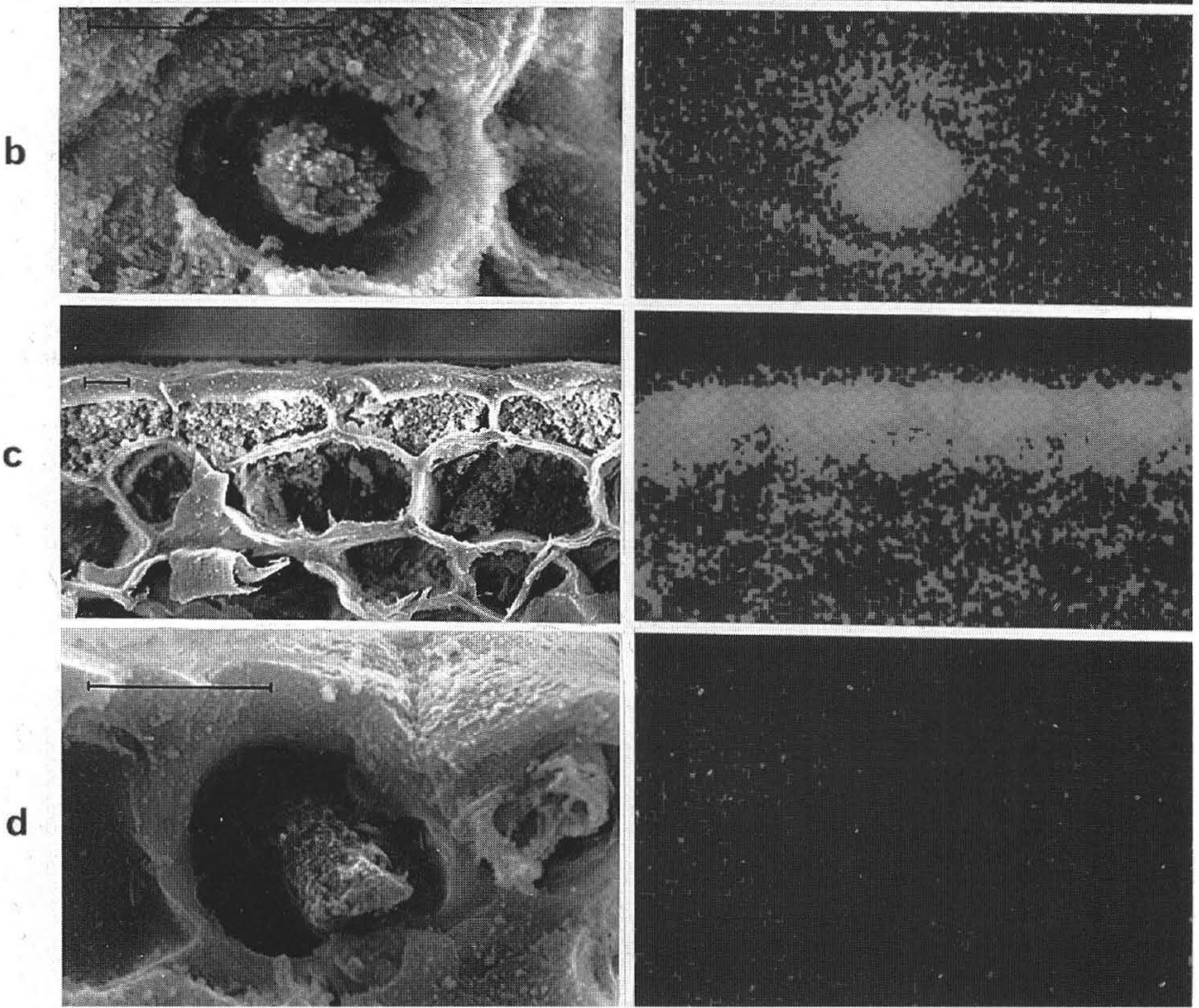

Fig. 5. Presence or absence of silica in epidermal cells. Left: SEM micrographs of cross sections; right: corresponding maps representing density of silica in regions photographed (highest densities of silica indicated white). a, Baxteria australis: spherical silica body; b, Kingia australis: spherical silica body; c, Dasypogon bromeliifolius: silica sand; d, Xanthorrhoea minor: silica absent. Scale bars $=10 \mu \mathrm{m}$. 
Surface waxes Epicuticular wax morphology may be significant for the higher-level systematics of some taxa. Barthlott \& Frolich (1983) and Frolich \& Barthlott (1988) identified several types of epicuticular wax, of which the Convallaria-type (small wax platelets clearly oriented in more or less parallel lines) is largely restricted to some genera of Asparagales, Liliales and Burmanniales, and the Strelitzia-type (long, often curly, extruded wax ribbons) to some commelinoid taxa: certain Arecanae, Commelinanae, Zingiberanae and Bromelianae (although there are exceptions, e.g. the Strelitzia-type occurs in Dracaena). However, these types are by no means ubiquitous in the groups in which they occur, so their absence is not necessarily significant. Barthlott \& Frolich (1983) and Frolich \& Barthlott (1988) reported neither type in the five out of six genera of Dasypogonaceae that they examined, and our results have confirmed this: surface waxes are present but not oriented in parallel lines or long wax ribbons. These results are therefore inconclusive with regard to the systematics of this group.

Stomata Anomocytic stomata (i.e. without subsidiary cells, using the terminology of Metcalfe 1961) are the most common mature stomatal type amongst Asparagales, although paracytic and tetracytic forms also occur, often in combination. Paracytic stomata have lateral pairs of subsidiary cells parallel to the long axis. Tetracytic stomata are surrounded by four subsidiary cells (two lateral and two polar). Both paracytic and tetracytic types are prevalent in the commelinoid clade, where anomocytic stomata are relatively rare. However, Tomlinson (1974) and others have suggested that an ontogenetic study is essential for systematic purposes, as similar mature types may be achieved by different ontogenetic pathways, and are therefore non-homologous. For example, in the paracytic stomata of Poaceae and many other commelinoid taxa (Cyperaceae, Juncaceae, Centrolepidaceae, Eriocaulaceae, Xyridaceae, Joinvilleaceae, some Commelinaceae, Marantaceae and Zingiberaceae), the subsidiary cells are derived by non-oblique divisions of the lateral contact cells adjacent to the meristemoid (guard cell mother cell). Similarly, in the tetracytic type of many commelinoid taxa (some Commelinaceae, Philydraceae, Cannaceae and Zingiberaceae), the subsidiary cells are derived from non-oblique divisions of the lateral and polar neighbouring cells. Conversely, the paracytic and tetracytic types of most non-commelinoid taxa (Agavaceae, some Amaryllidaceae, Asphodelaceae, Butomaceae, Cyclanthaceae, Orchidaceae, Philesiaceae, Pandanaceae) are often derived from oblique divisions of the neighbouring cells. However, this character is not entirely reliable as a taxonomic marker at the higher level. For example, some commelinoid taxa consistently have oblique cell divisions (e.g. Arecaceae, Flagellaria, Heliconiaceae, Pontederiaceae) and some non-commelinoid taxa have non-oblique divisions (e.g. Tecophilaeaceae). Other anomalous taxa are irregular (Dioscoreaceae) or with both types occurring (Strelitziaceae and Hypoxidaceae). Rasmussen (1983) discussed further developmental patterns in monocot stomata, notably the presence of either perigene cells (subsidiary cells derived from cells adjacent to the meristemoid) or mesogene cells (subsidiary cells derived from the meristemoid), but found little systematic correlation. Our results are therefore inconclusive for this character set, which needs further review among other monocotyledons to test homologies.

Cell wall ferulate Following Harris and Hartley's (1980) methods of examination of cell wall fluorescence to detect presence of polymer-bound ferulic acid, Rudall and Caddick (1994) analysed the taxa of Xanthorrhoeaceae sensu lato. They found positive results (ferulates present in cell walls) in Baxteria, Calectasia, Dasypogon, Kingia and Xerolirion, and negative results (cell wall ferulates absent) in Acanthocarpus, Chamaexeros, Lomandra, Romnalda and Xanthorrhoea. These results link the former group with the commelinoid clade, the latter with the non-commelinoid grade. Chase et al. (1995b) found this character to be the most consistent in distinguishing the commelinoid taxa from all other monocots. 
Pollen and ovules Both pollen and ovule characters have proved to be taxonomically useful in asparagoids (e.g. Chase, Rudall \& Conran, in prep.). Chanda \& Ghosh (1976) examined the pollen morphology of Acanthocarpus, Baxteria, Calectasia, Chamaexeros, Dasypogon, Kingia, Lomandra and Xanthorrhoea, but found no significant apomorphies, apart from similar sulculate grains in Acanthocarpus and Chamaexeros, and punctate surface sculpturing in Dasypogon and Kingia (Table 5). Baxteria has a unique 'unipantocolpate' pollen type, with reticulate surface sculpturing (as in Calectasia). The large genus Lomandra is palynologically diverse. It includes three species (L.endlicheri, L. leucocephala, L. micrantha) with spiraperturate grains, which led Chanda \& Ghosh (1976) to suggest that these species should be segregated into a separate genus, although according to Stevens (1978) there is no anatomical or morphological evidence to support this. Spiraperturate grains occur in a few unrelated groups, both dicots and monocots (Furness 1985), including some Eriocaulaceae, Costaceae, Crocus (Iridaceae) and also the isolated genus Aphyllanthes. They may be derived from sulculate types (Chandra \& Ghosh 1978) or inaperturate types (Furness 1985). Pollen of other putatively related arthropodioid genera, such as Thysanotus, would merit further investigation.

Rudall (1994) described the ovule and embryo sac in Xanthorrhoeaceae sensu lato, and recorded in Lomandra a markedly enlarged chalazal dermal layer of the nucellus, usually associated with large antipodals, which also occurs in other members of the recircumscribed family Lomandraceae: Arthropodium, Chamaexeros, Dichopogon, Eustrephus, Sowerbaea and Thysanotus. The massive starchy nucellus in Calectasia and Dasypogon differs from the nucellus types found in asparagoid taxa. The formation of the micropyle by the inner integument alone (Table 4) is also apparently an asparagoid character.

\section{Taxonomy}

Anatomical, embryological and molecular data indicate that Xanthorrhoeaceae sensu lato (Bedford et al. 1986) is a polyphyletic assemblage, with at least four generic groupings: (1) a Lomandra group (Acanthocarpus, Chamaexeros, Lomandra, Romnalda and Xerolirion), (2) Xanthorrhoea alone, (3) Dasypogon and Calectasia and (4) Kingia and Baxteria. These correspond closely to Fahn's (1954) anatomical groupings. The former two are asparagoid, the latter two commelinoid. Since their relationships are so broad, it is inappropriate to carry out a cladistic analysis here, as this would require comprehensive comparative data on many other monocot groups. However, with the existing data we propose that the ten genera of Xanthorrhoeaceae sensu lato be distributed in three recircumscribed families: Dasypogonaceae (Baxteria, Calectasia, Dasypogon and Kingia), Lomandraceae (Acanthocarpus, Chamaexeros, Lomandra, Romnalda and Xerolirion, together with other genera: Chase, Rudall and Conran in prep.) and Xanthorrhoeaceae sensu Dahlgren et al. (1985) (Xanthorrhoea).

Dasypogonaceae Dumort. (1829)

New circumscription. Genera included: Baxteria R.Br. ex Hook., Calectasia R.Br., Dasypogon R.Br., Kingia R.Br.

On the basis of $r b c \mathrm{~L}$ analysis (Chase et al. 1995a), cell wall ferulates (Rudall \& Caddick 1994), and presence of silica (this paper), Dasypogon, Calectasia, Kingia and Baxteria (Dasypogonaceae) belong in the commelinoid clade (Fig. 6) (Table 5). Dasypogon and Calectasia are similar to each other in several respects: vascular bundle structure, branched trichomes and stomata (Fahn 1954, this paper) and especially in ovule morphology (Rudall 1994) (Table 5). Kingia appears close to Baxteria on the basis of leaf anatomy, silica grain morphology (druse-like: this paper) and presence of substomatal cells (Fahn 1954). Since the family Dasypogonaceae sensu Brummitt (1982) comprised 
only Dasypogon and Kingia, it should be recircumscribed to include Calectasia and Baxteria, but in two informal groups (Dasypogon/Calectasia and Kingia/Baxteria). From $r b c \mathrm{~L}$ analysis (Chase et al. 1995a) Dasypogonaceae are among the first-branching families of the commelinoid clade (Fig. 6), close to palms. In the combined analysis of Chase et al. (1995b) they are together with the palms and Hanguana. However, relationships within the commelinoid clade are tentative at this stage, as there are many missing data. Habit and method of growth would support a relationship with palms, but ovule structure and silica position and morphology indicate an affinity with Rapateaceae.

Xanthorrhoeaceae Dumort. (1829)

Sensu Dahlgren et al. (1985). Genera included: Xanthorrhoea Sm. only

Xanthorrhoea is taxonomically isolated and correctly placed in a monogeneric family Xanthorrhoeaceae (Dahlgren et al. 1985), with obscure relationships. It differs from the other genera of Xanthorrhoeaceae sensu lato in several respects, such as number of ovules per ovary locule (Table 3) and and presence of a hypostase (Table 4), although in both of these respects it has the (probable) plesiomorphic asparagoid conditions. On the basis of inflorescence morphology, Waterhouse (1967) considered it close to Agavaceae, which it also resembles in vascular bundle structure (Fahn 1954), and presence of an STM. However, these characters are probably all homoplasious in Asparagales, at least to some extent. Molecular data (Chase et al. 1995a) put Xanthorrhoea in a phormioid-asphodeloid clade (Fig. 6). It is usually sister to Asphodelaceae, which includes genera with an STM such as Aloe, Asphodelus and Bulbine (Fig. 5), or sometimes sister to the phormioids, a (mainly) PhormiaceaeJohnsonieae group, including Caesia, Dianella, Drymophila, Geitonoplesium, Hemerocallis, Hensmannia, Johnsonia, Phormium, Pasithea, Stawellia and a few other (largely Australian) genera, lacking an STM. Xanthorrhoea differs from most of the other phormioid-asphodeloids in having successive microsporogensis (Rudall, unpublished), in which respect it resembles 'higher' asparagoids.

\section{Lomandraceae Lotsy (1911)}

To be recircumscribed. Genera included: Acanthocarpus Lehm., Chamaexeros Benth., Lomandra Labill., Romnalda P.F. Stevens, Xerolirion A.S. George and several other genera (Chase, Rudall and Conran in prep.).

The exact circumscription and relationships of the Lomandra-group require further analysis, since some genera are unknown for some of the critical characters. On the basis of similar leaf anatomy (Fahn 1954, this paper) and sulculate pollen (Chanda \& Ghosh 1976) Acanthocarpus and Chamaexeros seem to be closely allied. Acanthocarpus, Chamaexeros, Lomandra and Romnalda share similarities in leaf anatomy, such as enlarged outer bundle sheath cells and sclerenchyma girders from the inner bundle sheath (Table 5); however, these characters occur elsewhere and may well be homoplasious. On present evidence, the family Lomandraceae should therefore include at least Acanthocarpus, Chamaexeros, Lomandra and Romnalda (not Baxteria). Other characters, such as nucellus structure (Rudall 1994 and unpublished), presence of an STM (in Lomandra and Thysanotus: this paper and Rudall 1995) and rbcL (Chase et al. 1995a) further link Lomandra with the arthropodioids (Fig. 6): Arthropodium, Cordyline, Chamaescilla, Eustrephus, Sowerbaea, Thysanotus and Trichopetalum, although there are still gaps in the data sets. Several of these genera (e.g. Eustrephus, Sowerbaea, Thysanotus and Trichopetalum) have markedly tuberous roots. Eustrephus, Thysanotus and Trichopetalum all have fimbriate inner tepals. The family Lomandraceae should be recircumscribed to include all of these genera (Chase, Rudall \& Conran in prep.).

The relationships of Xerolirion, a monotypic genus from southern Western Australia, have always been problematical. It has sessile, reduced leaves and female flowers are 


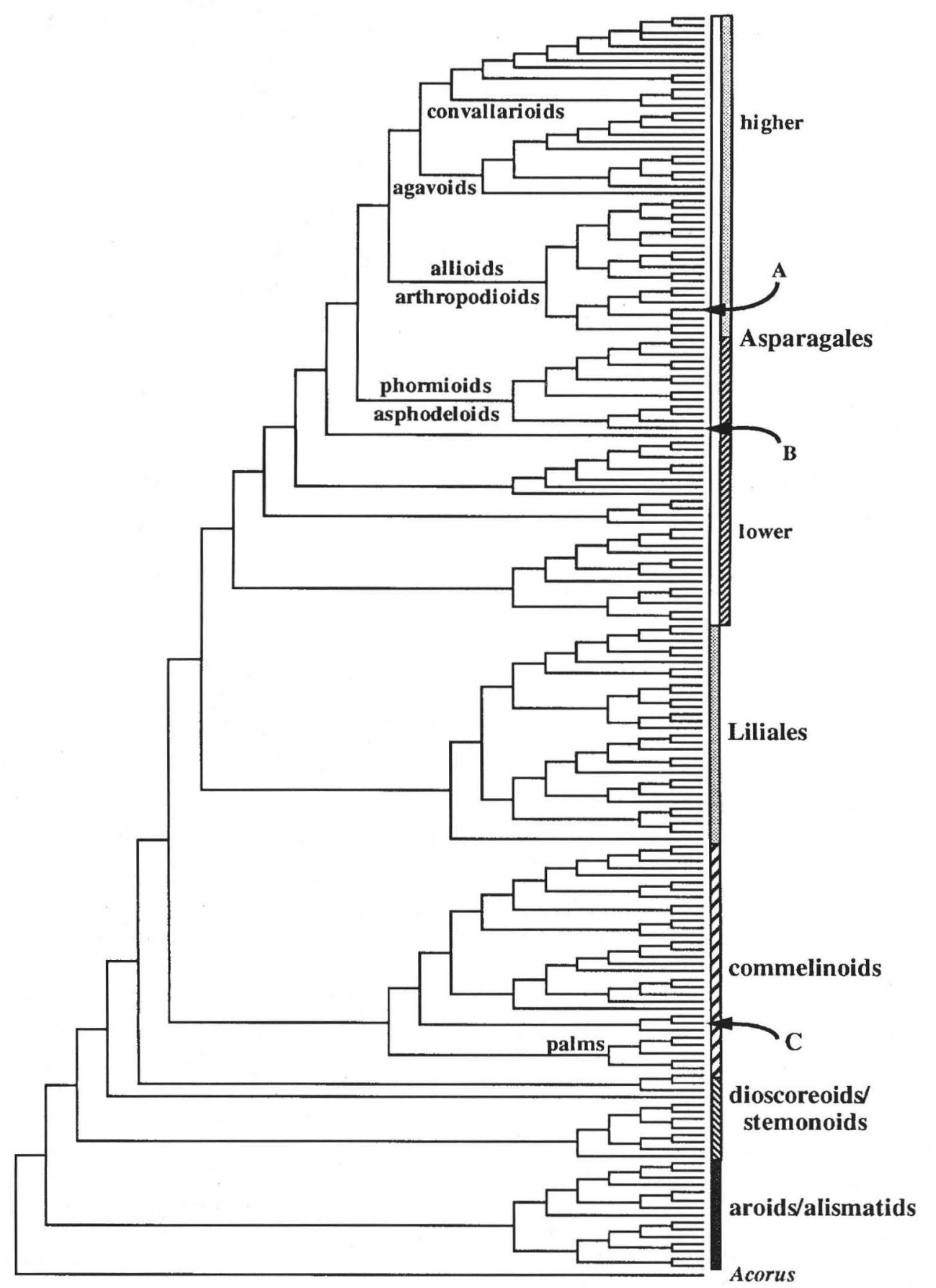

Fig. 6. Diagram based on $r b c \mathrm{~L}$ cladogram in Chase et al. (1995), showing relationships of some of the genera of Xanthorrhoeaceae sensu lato. $\mathrm{A}=$ Lomandra; $\mathrm{B}=$ Xanthorrhoea; $\mathrm{C}=$ Dasypogon. 
solitary and terminal, the male flowers in small cymes. The presence of cell wall ferulates (Rudall \& Caddick 1994) links it with the commelinoid clade, but lack of silica contradicts this. Other characters, such as anomocytic stomata and unbranched trichomes, link Xerolirion with the asparagoid clade, and in leaf anatomy it most closelly resembles the Lomandra-group. Recent $r b c \mathrm{~L}$ analysis has placed it with Lomandra.

\section{Acknowledgements}

We are grateful to Karen Wilson and Surrey Jacobs (Royal Botanic Gardens, Sydney), David Bedford (now Royal Tasmanian Botanical Gardens), Kingsley Dixon and Kathy Meney (Kings Park and Botanic Garden, Perth) and Peter Linder (University of Cape Town, South Africa), for their invaluable help, both in the field (with PJR), and discussion of monocot systematics, especially to David Bedford and other reviewers of the manuscript. Thanks are also due to Vicky Wilson, Liz Caddick and Janet Rusby (University of Bradford), who prepared some of the microscope slides and SEM material during their work experience at Kew, and Anna Lynch (Jodrell Lab, RBG, Kew), who helped with the $\mathrm{X}$-ray analysis. Liz Caddick, John Conran, Mel Duvall, James Hartwell and Hal Hills supplied DNA sequences.

\section{References}

Barthlott, W. \& Frolich, D. (1983) Mikromorphologie und Orientierungsmuster epicuticularer Wachse-Kristalloide: Ein neues systematisches Merkmal bei Monokotylen. Plant Syst. Evol. 142: 171-185.

Bedford, D.J., Lee, A.T., MacFarlane, T.D., Henderson, R.J.F. \& George, A.S. (1986) Xanthorrhoeaceae. Flora of Australia 46: 88-171.

Bentham, G. \& Hooker, J.D. (1880) Genera Plantarum. III. (Lovell Reeve \& Co.: London).

Brummitt, R.K. (1992) Vascular Plant Families and Genera (Royal Botanic Gardens: Kew).

Chanda, S. \& Ghosh, K. (1976) Pollen morphology and its evolutionary significance in Xanthorrhoeaceae. Pp. 527-559 in I.K. Ferguson \& J. Muller (eds), The Evolutionary Significance of the Exine (Academic Press: London).

Chase, M.W., Duvall, M.R., Hills, H.G., Conran, J.G., Cox, A.V., Eguiarte, L.E., Hartwell, J., Fay, M.F., Caddick, L.R., Cameron, K.M. and Hoot, S. (1995a) Molecular systematics of Lilianae. Pp. 109-137 in P.J. Rudall, P.J. Cribb, D.F. Cutler \& C.J.Humphries (eds), Monocotyledons: Systematics and Evolution (Royal Botanic Gardens: Kew).

Chase, M.W., Stevenson, D.W., Wilkin, P. \& Rudall, P.J. (1995b) Monocot systematics: a combined analysis. Pp. 685-730 in P.J. Rudall, P.J. Cribb, D.F. Cutler \& C.J.Humphries (eds), Monocotyledons: Systematics and Evolution (Royal Botanic Gardens: Kew).

Cronquist, A. (1981) An integrated system of classification of flowering plants (Columbia University Press: New York).

Dahl Møller, J. \& Rasmussen, H. (1984) Stegmata in Orchidales: character state distribution and polarity. Bot. J. Linn. Soc. 89: 53-76.

Dahlgren, R.M.T., Clifford, H.T. \& Yeo, P.F. (1985) The Families of the Monocotyledons (SpringerVerlag:Berlin).

Dahlgren, R.M.T. \& Rasmussen, F.N. (1983) Monocotyledon evolution; characters and phylogenetic estimation. Evol. Biol. 16: 255-395.

Duvall, M.R, Clegg, M.T., Chase, M.W., Clark, W.D., Kress, W.J., Hills, H.G., Eguiarte, L.E., Smith, J.F., Gaut, B.S., Zimmer, E.A. \& Learn, G.H. (1993) Phylogenetic hypotheses for the monocotyledons constructed from rbcL sequence data. Ann. Missouri Bot. Gard. 80: 607-619.

Fahn, A. (1954) The anatomical structure of the Xanthorrhoeaceae Dumort. Bot. J. Linn. Soc. 55: $158-184$.

Fahn, A. (1961) The anatomical structure of Xanthorrhoeaceae Dumort. and its taxonomic position. Pp. 155-160 in Recent advances in Botany. (University of Toronto Press).

Frolich, D. \& Barthlott, W. (1988) Mikromorphologie der epicuticularen Wachse und das System der Monokotylen. Tropische und Subtropische Pflanzenwelt 63: 1-135. 
Furness, C.A. (1985) A review of spiraperturate pollen. Pollen et spores 27: 307-320.

Hutchinson, J. (1934) The Families of Flowering Plants. II. Monocotyledons. (Clarendon Press: London).

Krause, K. (1930) Liliaceae. Pp. 227-386 in A.Engler and K.Prantl (eds), Die Natürlichen Pflanzenfamilien, ed. 2.

Metcalfe, C.R. (1961) The anatomical approach to systematics. General introduction with special reference to recent work on monocotyledons. Pp 146-150 in Recent advances in Botany. (University of Toronto Press).

Rudall, P. (1991) Lateral meristems and stem thickening growth in monocotyledons. Bot. Rev. 57: 150-163.

Rudall, P. (1994) The ovule and embryo sac in Xanthorrhoeaceae sensu lato. Flora 189: 335-351.

Rudall, P. (1995) New records of secondary thickening in monocotyledons. IAWA Journal 16: 261-268.

Rudall, P. \& Caddick, E. (1994) Investigation of the presence of phenolic compounds in monocot cell walls, using UV fluorescence microscopy. Ann. Bot. (London) 75: 483-491.

Rudall, P. \& Cutler, D.F. (1995) Asparagales: a reappraisal. Pp. 157-168 in P.J. Rudall, P.J. Cribb, D.F. Cutler \& C.J.Humphries (eds), Monocotyledons: Systematics and Evolution (Royal Botanic Gardens: Kew).

Staff, I.A. \& Waterhouse, J.T. (1981) The biology of arborescent monocotyledons, with special reference to Australian species. Pp. 216-257 in J.S. Pate \& A.J. McCombe (eds), The Biology of Australian plants (University of Western Australia Press: Nedlands).

Stevens, P.F. (1978) Generic limits in the Xeroteae (Liliaceae sensu lato). J. Arnold Arbor. 59: 129-155.

Stevenson, D.W. \& Loconte, H. (1995) Cladistic analysis of monocot families. Pp. 543-578 in P.J. Rudall, P.J. Cribb, D.F. Cutler \& C.J.Humphries (eds), Monocotyledons: Systematics and Evolution (Royal Botanic Gardens: Kew).

Tomlinson, P.B. (1974) Development of the stomatal complex as a taxonomic character in the monocotyledons. Taxon 23: 109-128.

Waterhouse, J.T. (1967) Some Aspects of the Status of the Family Xanthorrhoeaceae Hutchinson (Unpublished MSc Thesis, University of New South Wales: Sydney).

Waterhouse, J.T. (1987) The phylogenetic significance of Dracaena-type growth. Proc. Linn. Soc. New South Wales 109: 129-138.

\author{
Manuscript received 28 May 1995 \\ Manuscript accepted 14 December 1995
}

